\title{
Outbreak of salt poisoning in goats in the state of Pará, Brazil
}

\section{Surto de intoxicação por sal em caprinos no estado do Pará, Brasil}

\author{
Marcos Dutra Duarte ${ }^{1 *}$; Pedro Soares Bezerra Júnior ${ }^{2}$; Henrique dos Anjos \\ Bomjardim $^{3}$; Natália da Silva e Silva ${ }^{2}$; José Alcides Sarmento da Silveira'; Kelson \\ do Carmo Freitas Faial'; Tatiane Teles Albernaz ${ }^{1}$; José Diomedes Barbosa ${ }^{2}$
}

\begin{abstract}
The present study reports two outbreaks of salt poisoning in goats on a property in the state of Pará, Brazil. The outbreaks occurred in July and August 2011 when young and adult goats received a mineral mixture after approximately three days of restriction from the supplement. The animals were kept in barns with a high stocking density and had an inadequate supply of water. In the second outbreak, the goats were supplemented too with brewery residue added to $3.3 \%$ of the mixture mineral. From a flock of 191 goats, 12 animals (nine crossbreeds, two Anglo-Nubians and one Boer) showed nervous symptomatology, and the morbidity rate was $6.28 \%$. The most frequent clinical signs were head lowering, head tilt, muscle weakness, mydriasis and ataxia. Three goats died, four recovered spontaneously from the first outbreak, and five recovered from the second outbreak over three days after treatment with dexamethasone, thiamine and gradual water supply. The lethality rate was $25 \%$. In two animals, necropsy was performed, and no macro- or microscopic alterations in the nervous system or other organs were observed. These negative pathological findings indicate that the neurological clinical signs were initiated by functional disturbances in the central nervous system. In the brain, a high sodium concentration ( 3703 and $3675 \mathrm{ppm}$ ), compared with the reference values for cattle was detected. Normonatremia was observed in the sick goats, and hypernatremia was observed in the goats from the same lot of affected animals based on blood serum samples obtained before the first outbreak. These results pointed out that the goats were consuming high sodium concentrations. Normal values for the sick animals were assigned after rapid osmotic control via adequate water intake. We conclude that the salt poisoning on the goats occurred due to a high intake of the mineral mixture caused by management errors and associated with water restrictions.
\end{abstract}

Key words: Neurologic diseases. Small ruminants. Toxicity. Sodium chloride.

\section{Resumo}

Este trabalho relata dois surtos de intoxicação por sal em caprinos em uma propriedade no estado do Pará, Brasil. Os surtos ocorreram em julho e agosto de 2011 quando caprinos jovens e adultos receberam mistura mineral, após cerca de três dias de restrição do suplemento. Os animais estavam estabulados em baias com lotação acima do recomendado e os bebedouros não atendiam um adequado fornecimento de

1 Técnico Médico Veterinário, Instituto de Medicina Veterinária, Universidade Federal do Pará, UFPA, Castanhal, PA, Brasil. E-mail: duarte.marcos@gmail.com; jalcides@ufpa.br; tatyalbernaz@ufpa.br

2 Profs., Instituto de Medicina Veterinária, UFPA, Castanhal, PA, Brasil. E-mail: bezerraj@dmv.ufla.br; nataliasilva@ufpa.br; diomedes@ufpa.br

3 Discente de Doutorado, Programa de Pós-Graduação em Ciência Animal, PPGCAN, UFPA, Castanhal, PA, Brasil. E-mail: henriqueanjos18@hotmail.com

4 Pesquisador, Laboratório de Toxicologia "Edilson Brabo", Seção de Meio Ambiente, SAMAM, Instituto Evandro Chagas, IEC, Belém, PA, Brasil. E-mail: kelsonfaial@iec.pa.gov.br

* Author for correspondece 
água. No segundo surto, os caprinos foram suplementados adicionalmente com resíduos de cervejaria acrescido de 3,3\% de mistura mineral. De um total de 191 caprinos, nove mestiços, dois Anglonubianos e um Boer, apresentaram sintomatologia nervosa observando-se taxa de morbidade de 6,28\%. Os sinais clínicos mais frequentes foram fraqueza muscular, relutância ao movimento, rotação lateral da cabeça com o pescoço estendido e cabeça baixa. Três caprinos morreram, quatro do primeiro surto recuperaramse espontaneamente, e cinco recuperarm-se após três dias de tratamento com dexametasona, tiamina e fornecimento gradual de água. A taxa de letalidade foi de $25 \%$. Em dois animais necropsiados, não foram observadas alterações macro e microscópicas no sistema nervoso e em outros órgãos. Estes resultados negativos apontaram que os sinais clínicos neurológicos foram desencadeados por distúrbios funcionais no sistema nervoso central. No cérebro destes dois, havia altas concentrações de sódio (3703 e 3675 ppm), quando comparado com valores de referência para bovinos. Observou-se normonatremia nos caprinos doentes e hipernatremia nos caprinos pertencentes ao mesmo lote dos animais doentes em amostras de sangue obtidas antes do primeiro surto. Estes valores apontaram que os caprinos estavam consumindo altas concentrações de sódio. Os valores normais observados nos animais doentes foram atribuídos ao controle osmótico rápido após a devida ingestão de água. Conclui-se que a intoxicação por sal nos caprinos ocorreu devido à ingestão elevada da mistura mineral, após erro de manejo, associada à restrição hídrica.

Palavras-chave: Pequenos ruminantes. Doença Neurológica. Intoxicação. Cloreto de sódio.

\section{Introduction}

Sodium is the main cation of the extracellular fluid (ECF) (UNDERWOOD; SUTTLE, 1999; HOUPT, 2006; THOMPSON, 2007) and plays a key role, in the composition of the "osmotic skeleton" of the body and is maintained by the $\mathrm{Na}^{+} /$ $\mathrm{K}^{+}$pump, which actively transports sodium out of the cell (GUYTON; HALL, 1997). Salt poisoning can be classified in two ways. One form involves excessive sodium intake, and this acute intake is known as direct poisoning by sodium, acute sodium poisoning or acute hypernatremia. The other form of intoxication, which is more common, occurs when normal amounts of sodium are ingested but water is restricted, and it is known as indirect poisoning by sodium, chronic sodium poisoning or chronic hypernatremia (RADOSTITS et al., 2007; MAXIE; YOUSSEF, 2007; THOMPSON, 2007).

According to Radostits et al. (2007), the clinical description of salt poisoning in ruminants can be divided into subclinical, acute, subacute and chronic intoxication. In the acute and subacute forms, the clinical signs include thirst, dehydration, tachycardia, tachypnea, hyperthermia, apparent congestion of the mucous membranes, nervous signs, and digestive signs, such as gastroenteritis with bloat, abdominal discomfort and diarrhea (OHMAN, 1939; MOULE, 1945; SMITH; FYFE, 1971; TRUEMAN; CLAGUE, 1978; SANDALS, 1978; SCARRATT et al., 1985; PRINGLE; BERTHIAUME, 1988; RADOSTITS et al., 2007). The chronic form is rare in ruminants (SUMMERS et al., 1995; MAXIE; YOUSSEF, 2007), but the clinical signs described in cattle comprise drooling with foamy content in the mouth, muscle tremors, stiff gait, falls, muscle stiffness or pedaling movement when in decubitus and convulsions (LINDLEY, 1977). Subclinical poisoning occurs when lower salt concentrations are ingested, decreasing food intake, growth and milk production, with no typical clinical signs (RADOSTITS et al., 2007).

There are four reports in the literature on salt poisoning in sheep (MOULE, 1945; SMITH; FYFE, 1971; SCARRATT et al., 1985; DUARTE et al., 2014) and one in goats (BURONFOSSE, 1998). In Brazil, two reports are focused on salt poisoning in ruminants, with one investigating cattle (LEMOS et al., 1997) and the other investigating sheep (DUARTE et al., 2014). The morbidity and lethality rates of acute poisoning in cattle range from 8.3 to $100 \%$ and 0 to $80 \%$, respectively (SANDALS, 1978 ; TRUEMAN; CLAGUE, 1978; VAN LEEUWEN, 
1999). In sheep, these parameters range from 1.46 to $10.5 \%$ (morbidity) and 47.6 to $66.6 \%$ (lethality) (SMITH; FYFE, 1971; SCARRATT et al., 1985; DUARTE et al., 2014).

The present study aims to report the first outbreak of salt poisoning in goats in Brazil.

\section{Material and Methods}

\section{Epidemiological data}

The epidemiology and clinical pathology of the two outbreaks of neurological alterations in goats were evaluated on a rural property specialized in breeding of small ruminants, located in the municipality of Benevides, northeastern Pará State, Brazil. The outbreaks of neurological signs occurred in July and August 2011, and in addition to goats, sheep were also intoxicated (DUARTE et al., 2014). On suspicion of salt poisoning, the stalls of the flock and water troughs were investigated. The sources of salt and the supply history of the mineral mixture were also evaluated.

\section{Clinical pathological account}

A clinical examination was performed for 12 goats (01 to 12) with neurologic alterations, and necropsy was performed for two animals (05 and 06). The necropsy of one goat (animal 12) was not performed, because this animal was found dead in the process of autolysis. Fragments of the brain, spinal cord and various organs were collected and fixed in $10 \%$ formalin. The frontal cortex of the brain was also collected in $50 \mathrm{ml}$ Falcon tubes and stored at $-20^{\circ} \mathrm{C}$ for determination of the sodium concentrations.

The fragments in $10 \%$ formalin were processed routinely for histopathology via embedding in paraffin, sectioning at $5 \mu \mathrm{m}$ and staining with hematoxylin and eosin (HE) in the Animal Pathology Laboratory of the Federal University of Pará (Universidade Federal do Pará). The frozen samples of brain tissue were sectioned into thin slices using clean stainless steel blades, stored at $-20^{\circ} \mathrm{C}$ again for 24 hours and subjected to lyophilization using a lyophilizer $\left(\right.$ LIOTOP ${ }^{\circledR}$, TERRONI, São Paulo, Brazil) for 12 hours until completely dried. Subsequently, the samples were prepared and digested with nitric acid (PA, 65\%) (QUIMEX), hydrochloric acid (PA 30\%) (MERCK) and hydrogen peroxide (PA, 30\%) (BIOTEC) in a closed microwave digestion device (MARSXpress, CEM Corp. Matthews, NC, USA). The analytical blanks were prepared by the same procedure, without the addition of brain samples. After digestion, the sodium concentrations were analyzed by Inductively Coupled Plasma Optical Emission Spectrometry (ICP-OES) using an ICP-OES device (Vista-MPX CCD simultaneous, axial VARIAN) in an automatic sampling system (SPS-5) (NOMURA et al., 2005). The instrumental parameters of the ICP-OES were controlled by ICP Expert Vista software.

\section{Blood serum}

Blood samples of the jugular vein were collected in tubes without anticoagulant from six goats with clinical signs and from 36 goats without clinical signs. These blood serum samples from the healthy goats were collected before the first neurologic outbreak for flock health assessment when the goats were receiving daily mineral mixture. After, on suspicion of salt poisoning, these blood serum samples were utilized and determined the concentrations of sodium via the flame photometry method.

\section{Treatment}

Five goats were treated with dexamethasone (1 $\mathrm{mg} / \mathrm{kg})$ and thiamine $(10 \mathrm{mg} / \mathrm{kg})$, intramuscularly twice a day for two days and provided with a gradual water supply. 


\section{Results}

The neurological disturbance outbreaks occurred in two episodes in July and August 2011. In this period, 191 adult and young goats of the Boer and Anglo-Nubian breeds and their crossbreeds were maintained in semiconfinement with access to Brachiaria humidicola and Panicum maximum cv. Massai, adult animals, or in confinement, young animals. The goats were housed in barns with slatted floors in $25-$ or $50-\mathrm{m}^{2}$ stalls at stocking rate of 0.4 to $0.5 \mathrm{~m}^{2} /$ adult and $0.7 \mathrm{~m}^{2} /$ young animal. One water trough was included in the smaller stalls and two were included in the largest stalls, with a length of $51 \mathrm{~cm}$, width of $39 \mathrm{~cm}$ and depth of $14 \mathrm{~cm}$. The water flow was regulated by a buoy, and two animals could simultaneously access the trough via two openings in the wall of the stall (Figure 1). When housed, the goats received chopped Napier grass (Pennisetum purpureum) as forage and a complete mineral mixture in wooden troughs measuring 18 $\mathrm{cm} \times 18 \mathrm{~cm}$ x $10 \mathrm{~cm}$. The smaller stalls contained two wooden troughs and the largest stalls contained four troughs.

Figure 1. Salt poisoning in goats. At the end of the stall, the water trough opening allows two animals to access the trough simultaneously.

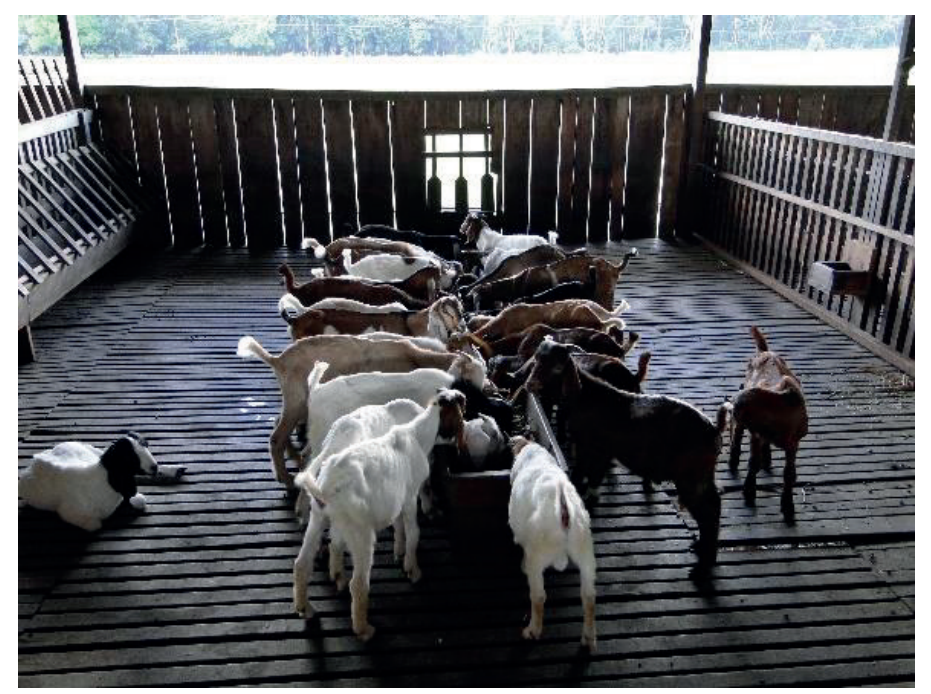

The goats became sick after the supply of mineral mixture that had been interrupted for three days, in the first outbreak and for two days, in the second. In the second outbreak, the clinical manifestation occurred one day after the mineral mixture supply. In this period, the goats received also brewery residue added to $3.3 \%$ mineral mixture ad libitum. Four goats became ill (01 to 04$)$ in the first outbreak and recovered spontaneously, and eight became ill (05 to 12$)$ in the second. After the second outbreak three of the goats died $(05,06$ and 12) and five recovered after treatment. Of the 12 animals affected, 11 goats were young and one was an adult (nine crossbred, two Anglo-Nubian and one Boer). The morbidity and lethality rates were $6.28 \%$ and $25 \%$, respectively.

In the two outbreaks, the goats were found in lateral recumbency or a standing posture with their head low and neck rotated laterally (Figure 2). In some animals, locomotion was difficult due to the collapse of the pelvic and thoracic limbs when movement began, and these animals remained in a recumbent position. The clinical signs were 
mainly related to the nervous system, although alterations in the digestive, circulatory, urinary and integumentary systems were also observed (Tables 1, 2 and 3). The main neurological signs were muscle weakness (7/12), changes in head and neck posture, such as lowering of the head (7/12), head tilt (5/12)
(Figure 3) and neck extension (3/12) (Tables 2 and 3) (Figure 4 and 5). The disease course varied from four hours to four days. Goats 05 and 06 were found in lateral recumbency and died after six and eight hours, respectively.

Figure 2. Salt poisoning in goats. One animal is in recumbency, four are in a standing posture, three animals show head tilt, and one animal presents an extended neck and head.

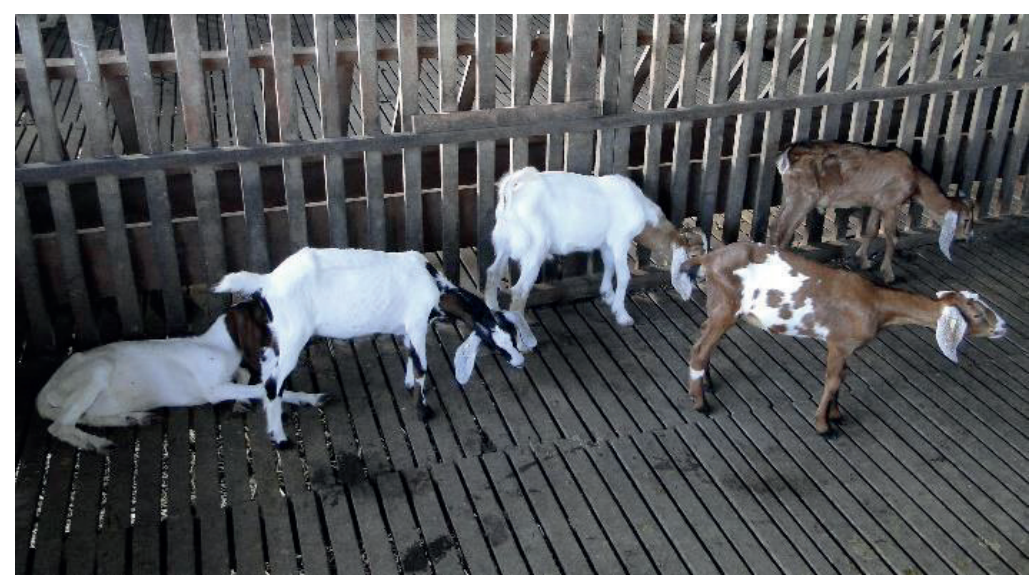

Table 1. Salt poisoning in goats. Clinical signs of the digestive, circulatory, urinary and integumentary systems.

\begin{tabular}{cccccc}
\hline Goat & $\begin{array}{c}\text { Ruminal } \\
\text { Hypomotility }\end{array}$ & Tachycardia & $\begin{array}{c}\text { Frequent } \\
\text { Urination }\end{array}$ & $\begin{array}{c}\text { Decreased } \\
\text { Skin Turgor }\end{array}$ & $\begin{array}{c}\text { Increased } \\
\text { Thirst }\end{array}$ \\
\hline 01 & NA $^{\mathrm{a}}$ & NA & $+++^{\mathrm{b}}$ & - & +++ \\
02 & NA & NA & +++ & - & +++ \\
03 & NA & NA & +++ & - & +++ \\
04 & NA & NA & +++ & - & +++ \\
05 & NA & NA & +++ & - & NA \\
06 & NA & NA & +++ & - & NA \\
07 & - & ++ & +++ & ++ & +++ \\
08 & $+^{c}$ & + & +++ & + & ++ \\
09 & $+^{c}$ & + & +++ & + & ++ \\
10 & $+^{c}$ & + & +++ & - & +++ \\
11 & $+^{c}$ & - & +++ & - & ++ \\
12 & NA & NA & +++ & - & +++ \\
\hline
\end{tabular}

${ }^{a}$ Clinical sign not evaluated

$\mathrm{b}+++$ Severe clinical sign, ++ moderate, + light, $(+)$ discrete and - absent

${ }^{\mathrm{C}}$ Clinical sign intensity was not recorded. 


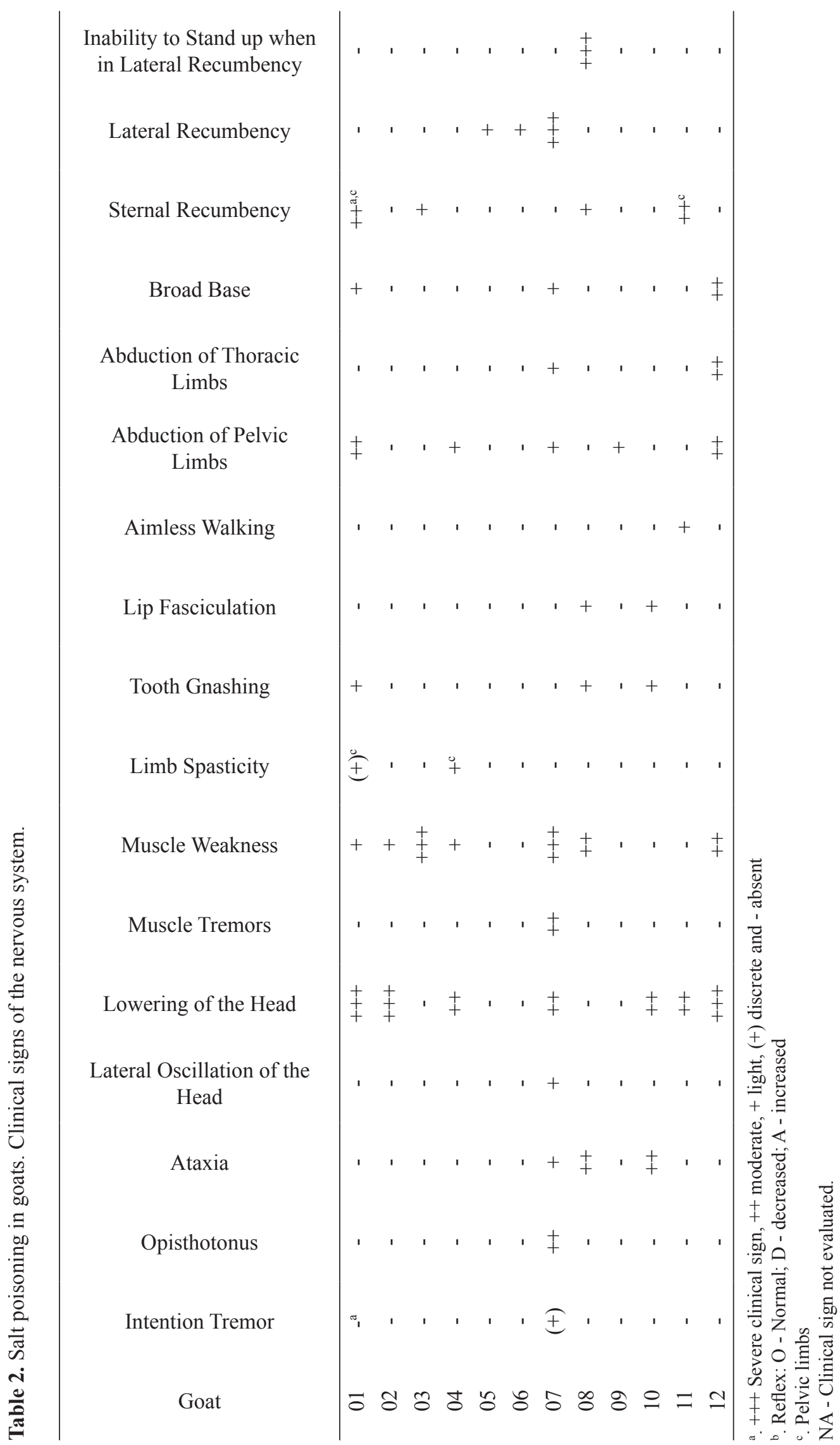


Table 3. Salt poisoning in goats. Clinical signs of the nervous system.

\begin{tabular}{cccccc}
\hline Goat & Dorsomedial Strabismus & Mydriasis & Neck Lateral Rotation & Neck Extension & Head Tilt \\
\hline 01 & + & ++ & - & - & +++ \\
02 & - & + & - & - & +++ \\
03 & - & + & - & - & - \\
04 & - & + & - & - & ++ \\
05 & - & - & - & - & - \\
06 & - & - & - & - & - \\
07 & + & -+ & - & + & +++ \\
08 & - & - & - & + & ++ \\
09 & - & - & - & + & - \\
10 & - & - & - & - & - \\
11 & - & - & +++ & - & - \\
12 & - & - & - & & - \\
\hline
\end{tabular}

a. +++ Severe clinical sign, ++ moderate, + light, $(+)$ discrete and - absent;

b. Reflex: O - Normal; D - decreased;

c. Head resting on the floor;

NA - Clinical sign not evaluated.

Figure 3. Salt poisoning in goats. Goat 01 with a standing posture, head tilt and low head.

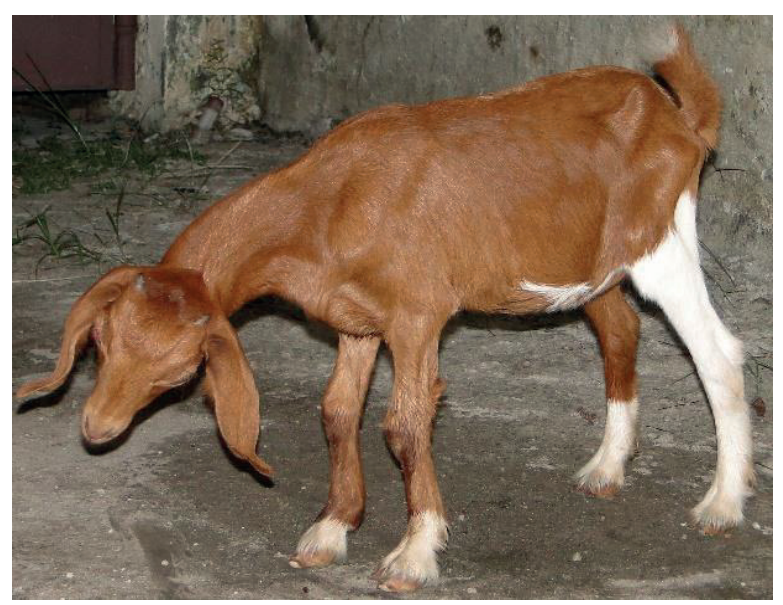

Figure 4. Salt poisoning in goats. Goat 10 with a standing posture and extended neck and head.

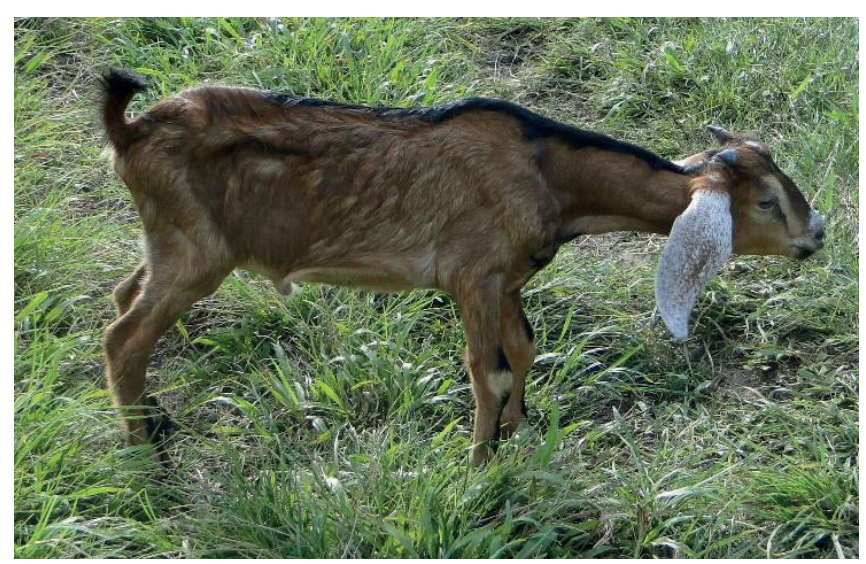


Figure 5. Salt poisoning in goats. Goat 07 with a standing posture, broad base and opisthotonus.

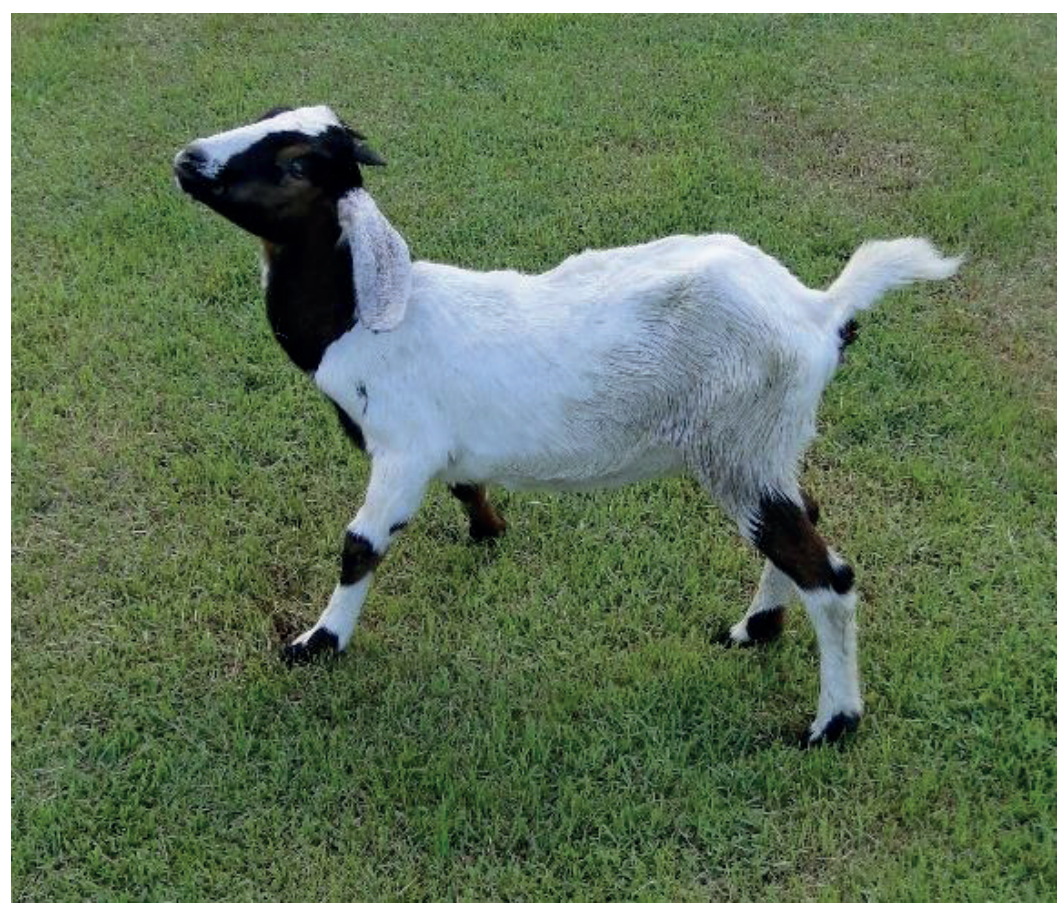

The mean serum concentrations of sodium and potassium in the sick goats (07 to 12 ) was 143.7 $\mathrm{mEq} / 1$ and $3.9 \mathrm{mEq} / 1$, respectively. In the goats without clinical signs from the same lot of animals affected in the first outbreak, the mean serum concentrations of sodium and potassium were 167 $\mathrm{mEq} / 1$ and $4.7 \mathrm{mEq} / 1$, respectively (Table 4).
No macroscopic or microscopic alterations were observed in the necropsied goats ( 05 and 06 ), and the sodium dosage in the brain tissue was 3703 and 3675 ppm, respectively.

All the treated goats recovered in three days.

Table 4. Salt poisoning in goats. Serum concentrations of sodium and potassium in intoxicated and clinically healthy goats that belonged to the same lot of animals affected in the first outbreak. (The samples in clinically healthy goats were collected before the onset of clinical signs, when the goats were receiving daily mineral mixture).

\begin{tabular}{cccc}
\hline Goats & $\mathrm{n}$ & {$[\mathrm{Na}]$} & {$[\mathrm{K}]$} \\
\hline 07 & 140 & 4.0 \\
& 08 & 148 & 4.7 \\
\multirow{3}{*}{ Intoxicated } & 09 & 144 & 4.2 \\
& 10 & 152 & 4.2 \\
& 11 & 132 & 2.7 \\
& 12 & 146 & 3.5 \\
& Mean & 143.7 & 3.9
\end{tabular}


continuation

\begin{tabular}{|c|c|c|c|}
\hline & 13 & 170 & 5.0 \\
\hline & 14 & 178 & 4.6 \\
\hline & 15 & 169 & 3.8 \\
\hline & 16 & 160 & 4.1 \\
\hline & 17 & 196 & 3.0 \\
\hline & 18 & 158 & 2.6 \\
\hline & 19 & 156 & 3.2 \\
\hline & 20 & 160 & 4.0 \\
\hline & 21 & 146 & 4.2 \\
\hline & 22 & 148 & 3.6 \\
\hline & 23 & 155 & 4.2 \\
\hline & 24 & 170 & 4.0 \\
\hline & 25 & 148 & 4.2 \\
\hline & 26 & 172 & 4.4 \\
\hline & 27 & 156 & 4.2 \\
\hline & 28 & 188 & 3.8 \\
\hline & 29 & 168 & 5.0 \\
\hline & 30 & 160 & 3.8 \\
\hline \multirow[t]{19}{*}{ Clinically healthy } & 31 & 172 & 3.8 \\
\hline & 32 & 158 & 4.6 \\
\hline & 33 & 148 & 2.8 \\
\hline & 34 & 164 & 4.8 \\
\hline & 35 & 150 & 4.6 \\
\hline & 36 & 158 & 3.6 \\
\hline & 37 & 152 & 3.2 \\
\hline & 38 & 146 & 3.0 \\
\hline & 39 & 166 & 5.4 \\
\hline & 40 & 154 & 4.0 \\
\hline & 41 & 190 & 7.0 \\
\hline & 42 & 188 & 6.2 \\
\hline & 43 & 190 & 7.6 \\
\hline & 44 & 198 & 8.6 \\
\hline & 45 & 190 & 7.8 \\
\hline & 46 & 196 & 5.5 \\
\hline & 47 & 178 & 8.4 \\
\hline & 48 & 162 & 6.4 \\
\hline & Mean & 167 & 4.7 \\
\hline \multicolumn{2}{|c|}{ Reference value $(\mathrm{mEq} / \mathrm{L})^{\mathrm{a}}$} & $142-155$ & $3.5-6.7$ \\
\hline
\end{tabular}

a. Kaneko (2008). 


\section{Discussion}

This is the first report of salt poisoning in goats in Brazil, and the diagnosis was made based on the epidemiology, clinical signs (BURONFOSSE, 1998; RADOSTITS et al., 2007), sodium concentrations in the serum and brain (THOMPSON, 2007) and positive response to treatment with thiamine, dexamethasone and gradual water supply as recommended by Niles (2004).

According to Ribeiro (1998), the stocking density was high, at 1.2 to $2 \mathrm{~m}^{2} /$ adult goat and 0.8 to $1.2 \mathrm{~m}^{2} / 3$ - to 6 -month-old animal, indicating overcrowding mainly in the adult goat stalls. According to Niles (2004), overcrowding is one of the causes of water restriction, in which the water supply is not sufficient. Furthermore, for an optimal water supply, the size of the water trough should allow simultaneous access by $10 \%$ of the herd, thus requiring $30 \mathrm{~cm}$ per animal (MCGREGOR, 2005). On this property, for lots of approximately 35 young goats, only two animals had access to the water trough simultaneously. The overcrowding and limited access to the water trough indicate that hydric restriction occurred in the present outbreaks. In most reports of salt poisoning in ruminants, water restriction is a risk factor for the development of outbreaks of salt poisoning (MOULE, 1945; SMITH; FYFE, 1971; LINDLEY, 1977; TRUEMAN; CLAGUE, 1978; SCARRATT et al., 1985; SENTURK; HUSEYIN, 2004).

Another important aspect in the epidemiology of the outbreak of salt poisoning in the studied herd was the onset of the disease one to two days after returning the mineral mixture supply that had been discontinued for two to three days. A similar situation was reported by Scarratt et al. (1985), who described salt poisoning in sheep after the animals had access to a mineral supplement that had been withdrawn for three weeks. Trueman and Clague (1978) also reported a similar episode in cattle, in which the mineral mixture supply was interrupted for several days, and when twice the normal amount of mineral mixture was supplied to the animals again, they ate it avidly and became ill. In addition to the probable excessive intake of salt through the mineral mixture, the goats of the second outbreak also received brewery residue containing 3.3\% mineral mixture, which was composed of $1.42 \%$ sodium chloride. This salt concentration is about five times higher than the $0.25 \%$ considered by McDowell (1999) as sufficient for confined animals. However, the supply of $4 \%$ sodium chloride in the feed is routinely used in northeastern Brazil to increase water consumption and reduce the risk of urolithiasis. However, in this situation, a constant supply of water must be offered to the animals (RIET-CORREA, 2010).

Some of the clinical signs previously reported in cases of salt poisoning in goats, such as opisthotonus, difficulty in standing up and an absence of rumination (BURONFOSSE, 1998), were also observed in the animals of the present study, and many of the other signs observed in the studied goats have been described in sheep and cattle (MOULE, 1945; SMITH; FYFE, 1971; LINDLEY, 1977; SANDALS, 1978; TRUEMAN; CLAGUE, 1978; SCARRATT et al., 1985; PRINGLE; BERTHIAUME, 1988; SENTURK; HUSEYIN, 2004). Changes in the head and neck postures were frequently observed in the present study. Lowering of the head was reported by Trueman and Clague (1978) in salt poisoning in cattle. This likely occurred due to a disturbance of the general proprioception of the cervical region, more specifically, of the cervical spinocerebellar tract. Broad base, ataxia and recumbency were commonly observed in the affected goats. Sternal or lateral recumbency has previously been described in the poisoning of ruminants (MOULE, 1945; LINDLEY, 1977). These clinical sings indicate proprioceptive deficits. In this case, the tracts most likely affected were the fasciculus Gracilis, Cuneatus, dorsal and ventral spinocerebellar (trunk and pelvic limbs) and cuneocerebellar and spinocerebellar rostral tracts (thoracic limbs). These tracts provide information 
to the cerebellum on the pelvic and thoracic limbs, trunk and neck positions during movement and during standing posture to allow adjustment of the posture, muscle tone, movement and balance (DE LAHUNTA; GLASS, 2009).

Keeping the neck extended, as observed in some of the animals of the present study, has never been reported as a clinical sign of salt poisoning. Cattle with pituitary abscesses that compress the hypothalamus often keep the head and neck extended in a posture called "looking at the stars" (DE LAHUNTA; GLASS, 2009). Functional disturbance to the diencephalon area may have caused these signs in the affected goats, because histopathological changes were not observed. The neck lateral rotation observed in goat 12 has not been previously described in salt poisoning. De Lahunta and Glass (2009) stated that rostral thalamic lesions might cause leaning, propulsive circling or ocular or head and neck deviation (pleurosthotonus), usually toward the side of the lesion. Mydriasis, as observed in five of the studied goats, has not been reported in other cases of salt poisoning in animals, but it has been reported in humans (DEGENARO; NYHAN, 1971). Changes in the pupillary reflex may accompany acute diseases that affect the forebrain, such as polioencephalomalacia caused by thiamine deficiency and lead poisoning. In these cases, the pupillary light reflex is usually preserved. However, when herniation of the occipital lobe under the tentorium occurs due to the edema, compression and displacement of the midbrain or oculomotor nerve or both, it will cause mydriasis with a decrease or absence of the pupillary light reflex (DE LAHUNTA; GLASS, 2009). Signs such as teeth gnashing and aimless walking have not been reported in other studies of salt poisoning in ruminants, but they have been observed in pigs (MARKS; CARR, 1989; FINNIE et al., 2010), and these signs indicate brain disease (RADOSTITS et al., 2007). Changes such as spasticity of limbs with hyperreflexia and opisthotonus have been observed in salt poisoning in cattle (LINDLEY,
1977; TRUEMAN; CLAGUE, 1978; PRINGLE; BERTHIAUME, 1988; SENTURK; HUSEYIN, 2004) and other clinical signs, such as dorsomedial strabismus and intention tremor, not yet described, have also been observed. These nervous signs related to salt poisoning outbreaks are usually caused by cerebral edema. However, in the goats affected by the outbreaks presented here these signs may have been related to functional disorders because cerebral edema was not observed in the necropsied animals.

The frequent urination observed in all animals of the present study has been previously described in cases of acute salt poisoning in cattle (RADOSTITS et al., 2007) and is most likely caused by the control mechanisms of osmolality and plasma volume. Hypernatremia causes increased water intake by stimulating thirst and increased water retention in the kidneys through the release of antidiuretic hormone (ADH) by the neurohypophysis (HOUPT, 2006). Increased water retention reduces osmolality, but the volume of the extracellular fluid expands and inhibits the renin-angiotensin-aldosterone system. As the direct and indirect reabsorption of sodium in the proximal tubule and by the action of aldosterone are blocked, respectively, greater sodium and water excretion are present in the urine. In addition, the stretching of baroreceptors, particularly in the left atrium, inhibits the release of ADH and atrial natriuretic peptide, which increase urinary sodium excretion (REECE, 2006). Increased thirst, as observed in many animals of the present study, has been described as a clinical sign of poisoning in goats (BURONFOSSE, 1998), sheep (SMITH; FYFE, 1971; SCARRATT et al., 1985) and cattle (SENTURK; HUSEYIN, 2004). This clinical sign is caused by the activation of control mechanisms of osmolality as described above.

The morbidity rate of $6.28 \%$ recorded in the present study is much smaller than that described by Buronfosse (1998), which was 53.3\%. In that report, goats escaped from their stalls and had access to large amounts of salt used to thaw icy roads. The authors did not mention if the animals received 
salt routinely. However, the increased appetite for salt most likely caused excessive intake of this substance. Despite the scarcity of information, this difference is likely related to the amount of salt ingested in each situation.

The mean serum concentrations of sodium and potassium of 36 goats from the same lot of animals affected in the first outbreak, in samples collected before the onset of the clinical signs when the goats were receiving daily mineral mixture, were $167 \mathrm{mEq} / \mathrm{L}$ and $4.7 \mathrm{mEq} / \mathrm{L}$, respectively. This sodium concentration is above the reference values for goats, which range from 142 to $155 \mathrm{mEq} / \mathrm{L}$ (KANEKO, 2008). The serum concentrations of sodium were not measured in the only previous report of salt poisoning in goats, but an increased serum concentration of sodium has been reported in other ruminants (PEARSON; KALLFELZ, 1982; SCARRATT et al., 1985; PRINGLE; BERTHIAUME, 1988; SENTURK; HUSEYIN, 2004). The sodium concentration proves that those animals were consuming excessive amounts of sodium chloride before. Furthermore, the inadequate water supply, as previously explained, certainly contributed to the occurrence of hypernatremia. The mean serum concentrations of potassium remained within the reference values for the species. However, the mean serum concentrations of sodium and potassium of the sick animals were within the normal reference values for the species. This can be explained by the fact that the animals drank water prior to the collection of blood samples. According to Carlson and Bruss (2008), after rehydration, those values tend to return or stay below the normal range.

The concentration of sodium in the brain of goats 05 and 06 was 3703 and 3675 ppm, respectively. No reference values exist in the literature for sodium concentrations in the brain of clinically healthy goats. However, Thompson (2007) states that despite the scarcity of data, the reference values should be similar to those adopted for cattle (upper limit of $1600 \mathrm{ppm}$ ). According to Thompson (2007), sodium concentrations above $2000 \mathrm{ppm}$ are confirmatory of salt poisoning in cattle. Because these results have been obtained for ruminants, these values may be similar between species.

The treatment performed was effective, and all treated animals recovered. When the whole herd is treated, or when it is not possible to monitor serum sodium, access to fresh water should be restricted to $0.5 \%$ of the body weight per hour (NILES, 2004). In the studied outbreak, access to water was restricted to small amounts, supplied three times a day. Although the water amount was not recorded, the procedure proved to be efficient. Administration of dexamethasone and thiamine are recommended as an auxiliary treatment for cerebral disorders (NILES, 2004).

The acute salt poisoning in goats must be differentiated from other diseases that cause digestive disorders, such as ruminal acidosis, which is caused by an excess of easily digestible carbohydrates and can be confirmed by examination of the ruminal fluid and finding a pH below 5.0 and by a history of ingestion of easily digestible carbohydrates. Other diseases that manifest cerebral clinical signs should also be distinguished from salt poisoning, such as polioencephalomalacia, which is associated with thiamine deficiency or an excess of sulfur. In the polioencephalomalacia associated with thiamine deficiency, the history usually reveals an abrupt change in food or an excess of easily digestible carbohydrates, and the clinical signs regress after the administration of thiamine at the onset of clinical signs. In the polioencephalomalacia associated with an excess of sulfur, the sulfur concentrations in the feed are usually above $0.4 \%$, and increased hydrogen sulfide in the rumen gas layer in the other animals of the herd may allow differentiation. In this disease, blindness is a common clinical sign, and malacia areas in cerebral cortex are also observed (LIMA et al., 2005). These clinical pathological finds were not observed for the goats in the studied outbreaks. At the studied property, the animals did not receive supplementation with concentrates. 
In cases of lead poisoning, the diagnosis is based on neurological clinical signs, the presence of materials with lead, such as battery plates, paint or contaminated pasture and water, and the diagnosis is confirmed by high lead concentrations in the liver and kidney (LEMOS et al., 2004; BARBOSA et al., 2014). No source of lead was available to the animals on the studied property. Poisoning by closantel, which is an antiparasitic salicylamide drug commonly used in small ruminants, occurs when this drug is used in overdosages. Neurological clinical signs are predominant in this disease, and blindness is frequently observed. Characteristic histopathological changes are also observed, such as myelin edema in the nervous system and optic nerve (FURLAN et al., 2009; RIVERO et al., 2015). Closantel was not administered to the goats in the studied case.

Based on the neurological clinical signs in association with the high mineral mixture intake, water restriction, high sodium concentrations in the serum and brain tissue and the lack of sick animals after returning to the regular mineral mixture supply, we conclude that the goats were intoxicated by salt.

\section{Conflict of interest}

The authors declare no conflict of interest.

\section{Acknowledgments}

The authors would like to thank Pró-Reitoria de Pesquisa e Pós Graduação da Universidade Federal do Pará (PROPESP/UFPA) for financial support and scholarships.

\section{References}

BARBOSA, J. D.; BOMJARDIM, H. A.; CAMPOS, K. F.; DUARTE, M. D.; BEZERRA JÚNIOR, P. S.; GAVA, A.; SALVARANI, F. M.; OLIVEIRA, C. M. C. Lead poisoning in cattle and chickens in the state of Pará, Brazil. Pesquisa Veterinária Brasileira, Rio de Janeiro, v. 34, n. 11, p. 1077-1080, 2014.
BURONFOSSE, F. Intoxication par le chlorure de sodium dans um élevage de chèvres. Le Point Vétérinarie, Puteaux, v. 29, n. 1, p. 1345-1346, 1998.

CARLSON, G. P.; BRUSS, M. Fluid, electrolyte, and acid-base balance. In: KANEKO, J. J. (Ed.). Clinical biochemistry of domestic animals. $6^{\text {th }}$ ed. San Diego: Academic Press, 2008. p. 529-559.

DE LAHUNTA, A.; GLASS, E. Veterinary neuroanatomy and clinical neurology. $3^{\text {th }}$ ed. Missouri: ST. Louis Saunders Elsevier, 2009. 552 p.

DEGENARO, F.; NYHAN, W. L. Salt - a dangerous antidote. The Journal of Pediatrics, New York, v. 78, n. 6, p. 1048-1049, 1971.

DUARTE, M. D.; BEZERRA, P. S. J.; LIMA, D. H. S.; BOMJARDIM, H. A.; OLIVEIRA, C. M. C.; SILVA, N. S.; FAIAL, K. C. F.; BARBOSA, J. D. Surto de intoxicação por sal em ovinos no estado do Pará. Pesquisa Veterinária Brasileira, Rio de Janeiro, v. 34, n. 11, p. 1061-1068, 2014.

FINNIE, J. W.; BLUMBERGS, P. C.; WILLIAMSON, M. M. Alzheimer type II astrocytes in the brains of pigs with salt poisoning (water deprivation/intoxication). Australian Veterinary Journal, Sydney, v. 88, n. 10, p. 405-407, 2010.

FURLAN, F. H.; LUCIOLI, J.; BORELLI, V.; FONTEQUE, J. H.; STOLF, L.; TRAVESSO, S. D.; GAVA, A. Intoxicação por closantel em ovinos e caprinos no estado de Santa Catarina. Pesquisa Veterinária Brasileira, Rio de Janeiro, v. 29, n. 1, p. 89-93, 2009.

GUYTON, A. C.; HALL, J. E. Tratado de fisiologia médica. $9^{\text {th }}$ ed. Rio de Janeiro: Guanabara Koogan, 1997. $1014 \mathrm{p}$.

HOUPT, T. R. Água e eletrólitos. In: REECE, W. O. (Ed.). Dukes fisiologia dos animais domésticos. $12^{\text {th }} \mathrm{ed}$. Rio de Janeiro: Guanabara Koogan, 2006. p. 11-23.

KANEKO, J. J. Clinical biochemistry of domestic animals. $6^{\text {th }}$ ed. San Diego: Academic Press, 2008. 928 p.

LEMOS, R. A. A.; DRIEMEIER, D.; GUIMARÃES, E. B.; DUTRA, I. S.; MORI, A. E.; BARROS, C. S. L. Lead poisoning in cattle grazing pasture contaminated by industrial waste. Veterinary and Human Toxicology, Manhattan, v. 46, n. 6, p. 326-328, 2004.

LEMOS, R. A. A.; NAKAZATO, L.; BARROS, C. S. L.; GATTAS, C. B. A.; BONILLA, R. Meningoencefalite eosinofílica em bovinos no Estado de Mato Grosso do Sul. Arquivos do Instituto Biológico, São Paulo, v. 64, p. 43, 1997. Suplemento.

LIMA, E. F.; RIET-CORREA, F.; TABOSA, I. M.; DANTAS, A. F. M.; MEDEIROS, J. M.; SUCUPIRA 
JÚNIOR, G. Polioencefalomalácia em caprinos e ovinos na região semi-árida do Nordeste do Brasil. Pesquisa Veterinária Brasileira, Rio de Janeiro, v. 25, n. 1, p. 9-14, 2005.

LINDLEY, W. H. Water deprivation in cattle. Journal of the American Veterinary Medical Association, Schaumburg, v. 171, n. 1, p. 439-440, 1977.

MARKS, S. L.; CARR, J. Water deprivation in weaned pigs. Veterinary Record, London, v. 125, n. 18, p. 460, 1989.

MAXIE, M. G.; YOUSSEF, S. Nervous system. In: MAXIE, M. G. (Ed.). Jubb, Kennedy \& Palmer's pathology of domestic animals. $5^{\text {th }}$ ed. Edinburgh: Saunders Elsevier, 2007. v. 1, p. 281-457.

MCDOWELL, L. R. Minerais para ruminantes sob pastejo em regiões tropicais, enfatizando o Brasil. $3^{\text {th }} \mathrm{ed}$. Gainsville: University of Florida, 1999. 92 p.

MCGREGOR, B. A. Suggested water provision for goats. In: MCGREGOR, B. A. (Ed.). Nutrition and management of goats in drought. Attwood: Rural Industries Research and Development Corporation, 2005. p. 57-58.

MOULE, G. R. Salt poisoning in sheep following evaporation of saline water. Australian Veterinary Journal, Sydney, v. 21, n. 1, p. 37-38, 1945.

NILES, G. Metals and minerals. Sodium. In: PUMLEE, K. (Ed.). Clinical veterinary toxicology. Missouri: Mosby, 2004. p. 218-229.

NOMURA, C. S.; SILVA, C. S.; NOGUEIRA, A. R. A.; OLIVEIRA, P. V. Bovine liver sample preparation and micro-homogeneity study for $\mathrm{Cu}$ and $\mathrm{Zn}$ determination by solid sampling electrothermal atomic absorption spectrometry. Spectrochimica Acta Part B, Amsterdam, v. 60, n. 5, p. 673-680, 2005.

OHMAN, A. F. S. Poisoning of cattle by saline bore water. Australian Veterinary Journal, Sydney, v. 15, $n$. 1, p. 37-38, 1939.

PEARSON, E. G.; KALLFELZ, F. A. A case of presumptive salt poisoning (water deprivation) in veal calves. Cornell Veterinarian, Ithaca, v. 72, n. 2, p. 142-149, 1982.

PRINGLE, J. K.; BERTHIAUME, L. M. M. Hypernatremia in calves. Journal of Veterinary Internal Medicine, Denver, v. 2, n. 2, p. 66-70, 1988.

RADOSTITS, O. M.; GAY, C. C.; HINCHCLIFF, K. W.; CONSTABLE, P. D. Diseases associated with inorganic and farm chemicals. In: RADOSTITS, O. M.; GAY, C. C.; HINCHCLIFF, K. W.; CONSTABLE, P. D. (Ed.). Veterinary medicine: a textbook of the diseases of cattle, horses, sheep, pigs and goats. $10^{\text {th }} \mathrm{ed}$. Edinburgh: Saunders Elsevier, 2007. p. 1824-1826.
REECE, W. O. Função renal nos mamíferos. In: REECE, W. O. (Ed.). Dukes fisiologia dos animais domésticos. $12^{\text {th }}$ ed. Rio de Janeiro: Guanabara Koogan, 2006. p. 67-96.

RIBEIRO, S. D. A. Instalações. In: RIBEIRO, S. D. A. (Ed.). Caprinocultura: criação racional de caprinos. São Paulo: Nobel, 1998. p. 129-156.

RIET-CORREA, F. Suplementação mineral em pequenos ruminantes. In: TOKARNIA, C. H.; PEIXOTO, P. V.; BARBOSA, J. D.; BRITO, M. F.; DÖBEREINER, J. (Ed.). Deficiências minerais em animais de produção. Rio de Janeiro: Helianthus, 2010. p. 172-185.

RIVERO, R.; MATTO, C.; SOARES, M. P.; ADRIEN, M. L. Accidental and experimental closantel intoxication in Uruguayan sheep. Pesquisa Veterinária Brasileira, Rio de Janeiro, v. 35, n. 7, p. 599-604, 2015.

SANDALS, W. C. D. Acute salt poisoning in cattle. Canadian Veterinary Journal, Ottawa, v. 19, n. 5, p. 136137, 1978.

SCARRATT, W. K.; COLLINS, T. J.; SPONENBERG, D. P. Water deprivation-sodium chloride intoxication in a group of feeder lambs. Journal of the American Veterinary Medical Association, Schaumburg, v. 186, n. 9, p. 977-978, 1985.

SENTURK, S.; HUSEYIN, C. Salt poisoning in beef cattle. Veterinary and Human Toxicology, Manhattan, v. 46, n. 1, p. 26-27, 2004.

SMITH, B.; FYFE, B. H. Suspected acute salt poisoning in sheep. The New Zealand Veterinary Journal, Wellington, v. 19, n. 9, p. 220-221, 1971.

SUMMERS, B. A.; CUMMINGS, J.; DE LAHUNTA, A. Degenerative diseases of the central nervous system: salt poisoning. In: SUMMERS, B. A.; CUMMINGS, J.; DE LAHUNTA, A. (Ed.). Veterinary neuropathology. St Louis: Mosby, 1995. p. 254-255.

THOMPSON, L. J. Sodium chloride (salt). In: GUPTA, R. C. (Ed.). Veterinary toxicology: basic and clinical principles. New York: Academic Press, 2007. p. 461-464.

TRUEMAN, K. F.; ClAGUE, D. C. Sodium chloride poisoning in cattle. Australian Veterinary Journal, Sydney, v. 54, n. 2, p. 89-91, 1978.

UNDERWOOD, E. J.; SUTTLE, N. F. Sodium and chlorine. In: UNDERWOOD, E. J.; SUTTLE, N. F. (Ed.). The mineral nutrition of livestock. $3^{\text {th }}$. ed. Oxon: CABI Publishing, 1999. p. 185-212.

VAN LEEUWEN, J. A. Salt poisoning in beef cattle on costal pasture in Prince Edward 1sland. Canadian Veterinary Journal, Ottawa, v. 40, n. 5, p. 347-348, 1999. 